\title{
PENGARUH SOCIAL MEDIA, ELECTRONIC WORD OF MOUTH, BRAND IMAGE, DAN PERCEIVED VALUE TERHADAP PURCHASE INTENTION KONSUMEN PADA SITUS ONLINE TOKOPEDIA
}

\author{
Erwin \\ Program Studi Magister Manajemen Universitas Tarumanagara \\ erwin.prastjand@gmail.com
}

Masuk : 07-12-2020, revisi : 21-12-2020, diterima untuk diterbitkan : 22-12-2020

\begin{abstract}
This study aims to determine the effect of social media, electronic word of mouth, brand image, and perceived value of purchase intention. The sampling technique in this study is nonprobability sampling by purposive sampling using a quantitative approach by distributing questionnaires to 200 respondents. The data analysis method used in this study is multiple linear regression analysis. Operational variables using the Likert scale method of validity used a computer measuring instrument that is SPSS 25.0. The results showed that social media have a significant and positive effect, electronic word of mouth has a significant and positive effect, brand image has a significant and positive effect, perceived value has a significant and positive effect on purchase intention. In this study, the perceived value is the most influences of purchase intention.
\end{abstract}

Keywords: Social Media, Electronic Word of Mouth, Brand Image, Perceived Value, Purchase Intention

Abstrak: Penelitian ini bertujuan untuk mengetahui pengaruh social media, electronic word of mouth, brand image, dan perceived value terhadap purchase intention. Teknik pengambilan sampel pada penelitian ini adalah nonprobability sampling dengan cara purposive sampling menggunakan pendekatan kuantitatif dengan menyebarkan kuesioner kepada 200 responden. Metode analisis data yang digunakan dalam penelitian ini adalah analisis regresi linier berganda. Variabel operasional menggunakan metode skala Likert validitas digunakan alat ukur komputer yaitu SPSS 25.0. Hasil penelitian menunjukkan bahwa social media positif signifikan, electronic word of mouth positif signifikan, brand image positif signifikan, perceived value positif signifikan terhadap purchase intention. Dalam penelitian ini, perceived value paling berpengaruh terhadap purchase intention.

Kata Kunci: Social Media, Electronic Word of Mouth, Brand Image, Perceived Value, Purchase Intention

\section{PENDAHULUAN}

Perkembangan teknologi informasi dan komunikasi saat ini mengalami kemajuan yang sangat pesat dibuktikan dengan mudahnya penggunaan akses internet dimana selain untuk mendapatkan informasi juga digunakan untuk sosial media, bisnis dan sebagainya. Fenomena pesatnya pertumbuhan sosial media, memunculkan sebuah trend baru dalam komunikasi pemasaran pada perusahaan ataupun UKM dalam bentuk dampak positif berupa efektivitas dan efisiensi. Direktur Jenderal Penyelenggaraan Pos dan Informatika Kominfo, Ahmad M. Ramli mengemukakan jumlah pengguna internet di Indonesia akhir September 2020 tercatat sekitar 175,5 juta jiwa dari jumlah populasi sebanyak 268.583.016 penduduk (Mursid, 2020). Dibandingkan tahun sebelumnya jumlah ini mengalami kenaikan 25 juta atau sekitar 17 persen. Pertambahan jumlah pengguna internet tentunya akan membuat perubahan dalam lingkungan pemasaran dan sejumlah pemasar akan memikirkan strategi dan cara terbaru untuk melakukan promosi pemasaran produk atau jasa. Pemanfaatan internet sebagai bagian dari proses bisnis, dimana sosial media menawarkan cara baru bagi perusahaan dan konsumen untuk saling 
terlibat satu sama lain. Keterlibatan pada sosial media meliputi segala tindakan yang menimbulkan interaksi terhadap konten yang tersedia di sosial media, sehingga konsumen terbiasa melihat atau mencari produk review secara online ketika konsumen mengumpulkan informasi mengenai suatu produk sebelum mereka melakukan keputusan pembelian. Dan dari situlah kemudian terbentuk minat beli dari konsumen atau biasa disebut sebagai purchase intention. Menurut Kotler dan Keller (2012), purchase intention adalah selera masing-masing orang yang menjadi dasar pemilihan sesuatu, minat membeli yang menunjukkan pada kecenderungan untuk lebih menyukai produk atau jasa dengan merek tertentu.

Purchase intention dipengaruhi beberapa faktor. Menurut Prasad et al. (2017), purchase intention dipengaruhi oleh variabel social media dan electronic word of mouth yang mempunyai hubungan yang positif terhadap purchase intention. Lien et al. (2015) menemukan bahwa variabel brand image mempunyai hubungan positif terhadap purchase intention. Faktor lainnya yang mempengaruhi purchase intention adalah perceived value. Lim et al. (2014) mendefinisikan "Perceived value refers to the preference or evaluation of whether a products attributes can meet its needs and satisfaction in a situation." bahwa perceived value mengacu pada preferensi atau evaluasi apakah suatu atribut produk dapat memenuhi kebutuhan dan kepuasannya dalam situasi tertentu.

Tujuan penelitian ini adalah untuk mengetahui pengaruh social media, electronic word of mouth, brand image, dan perceived value terhadap purchase intention konsumen pada situs online Tokopedia. Hasil penelitian ini diharapkan agar perusahaan khususnya situs online Tokopedia semakin memperhatikan faktor social media, electronic word of mouth, brand image, dan perceived value dalam kegiatan operasional perusahaan. Hal ini dikarenakan dari keempat faktor atau variabel tersebut menunjukkan pengaruh dalam menciptakan suatu keputusan oleh konsumen atau calon konsumen yang akan meningkatkan minat beli konsumen.

\section{TELAAH KEPUSTAKAAN}

\section{Social Media}

Menurut Kotler dan Keller (2016), social media adalah "online activities and programs designes to engage customers or prospects and directly or indirectly raise awareness, improve image, or elicit sales of products and services". Media sosial merupakan suatu aktivitas komunikasi pemasaran yang menggunakan media elektronik (online) dalam menarik konsumen atau perusahaan dalam berbagai bentuk (gambar, tulisan, dan lain-lain) untuk meningkatkan kesadaran, citra perusahaan, dan untuk meningkatkan penjualan. Menurut penelitian Prasad et al. (2017) mengemukakan bahwa social media dan electronic word of mouth memiliki hubungan yang positif terhadap purchase intention.

\section{Electronic Word Of Mouth (EWOM)}

Menurut Litvin et al. (2008) dalam Priansa (2016) menyatakan bahwa electronic word of mouth merupakan komunikasi sosial dalam internet di mana penjelajah web saling mengirimkan maupun menerima informasi terkait dengan produk secara online. Menurut penelitian Prasad et al. (2019) mengemukakan bahwa social media dan electronic word of mouth memiliki hubungan yang positif terhadap purchase intention.

\section{Brand Image}

Menurut Kotler dalam Lenarto et al. (2018) mendefinisikan brand image adalah persepsi yang dimiliki oleh konsumen saat pertama kali mendengar slogan yang diingat dan tertanam di benak konsumen. Brand image memainkan peran penting dalam membedakan merek dalam kategori produk atau merek yang serupa. Dalam hal ini peneliti berpendapat bahwa brand image adalah sebuah persepsi, identitas, gambaran umum, dan kesan yang dimiliki konsumen terhadap suatu merek/brand yang ditawarkan oleh suatu perusahaan dengan para pesaingnya. Menurut penelitian Lien et al. (2015) menemukan bahwa variabel brand image mempunyai hubungan positif terhadap purchase intention. Bahwa peningkatan brand image akan memperkuat niat konsumen untuk melakukan pembelian. 


\section{Perceived Value}

Menurut Zeithaml (1988), "The perceived value of customers is the result of a trade-off between perceived benefits and prices paid, and it is quantified in the form of benefits or price." Perceived value adalah hasil dari trade-off antara manfaat yang dirasakan dan harga yang dibayarkan, dan itu diukur dalam bentuk manfaat atau harga. Moslehpour et al. (2021) menyatakan bahwa konsumen cenderung memilih produk atau layanan yang meningkatkan persepsi nilai mereka. Dengan kata lain, semakin tinggi perceived value suatu produk atau layanan, semakin besar kemungkinan konsumen akan berniat untuk membeli produk. Menurut penelitian Yuan et al. (2020) mengemukakan bahwa perceived value berpengaruh positif terhadap purchase intention.

\section{Purchase Intention}

Menurut Wang dan Tsai (2014) dalam Resmawa (2017), purchase intention adalah tahapan dimana konsumen melakukan pengevaluasian terhadap informasi yang diterima. Purchase intention dapat diartikan sebagai kemungkinan bahwa konsumen akan melakukan pembelian produk tertentu. Kesediaan konsumen untuk membeli memiliki probabilitas yang lebih tinggi, walaupun konsumen belum tentu benar-benar membelinya. Purchase intention ditentukan oleh manfaat dan nilai yang dirasakan oleh konsumen.

\section{Kerangka Pemikiran}

Dasar pemikiran dan fokus dari penelitian ini adalah untuk mengkaji pengaruh dari variabel-variabel independen yaitu social media, electronic word of mouth, brand image, dan perceived value yang memiliki pengaruh terhadap purchase intention sebagai variabel dependen pada konsumen situs online Tokopedia. Berikut ini adalah model kerangka pemikiran pada penelitian ini:

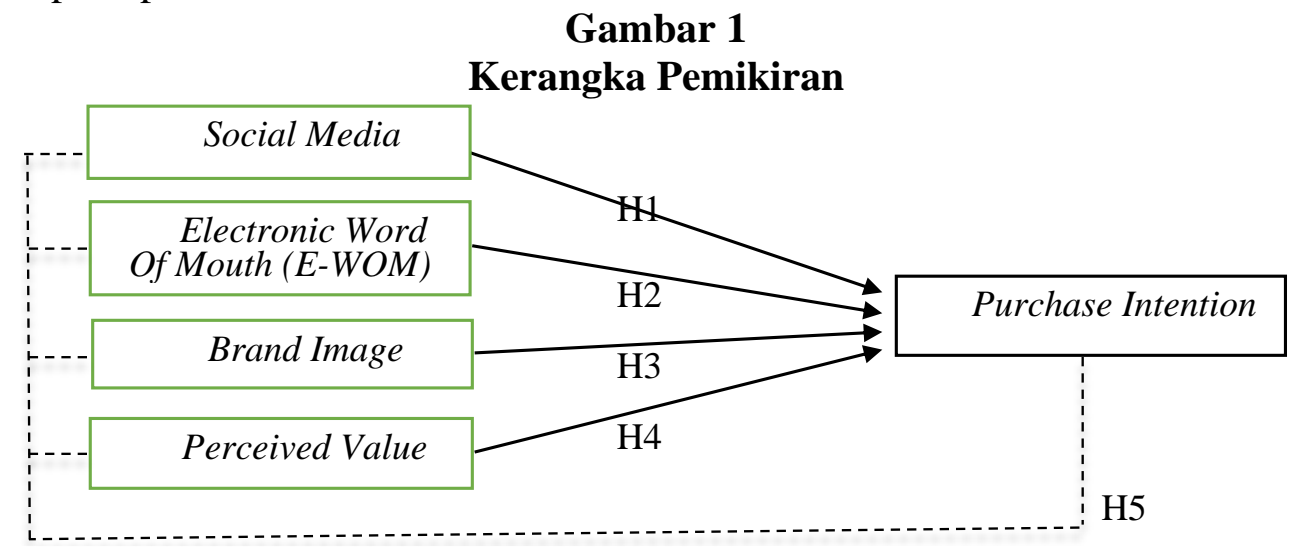

Berdasarkan kerangka pemikiran penelitian, maka dalam penelitian ini dapat dirumuskan beberapa hipotesis sebagai berikut:

H1 : Social Media berpengaruh secara signifikan terhadap Purchase Intention

$\mathrm{H} 2$ : Electronic Word Of Mouth (E-WOM) berpengaruh secara signifikan terhadap Purchase Intention

H3 : Brand Image berpengaruh secara signifikan terhadap Purchase Intention

$\mathrm{H} 4$ : Perceived Value berpengaruh secara signifikan terhadap Purchase Intention

H5 : Social Media, Electronic Word Of Mouth (E-WOM), Brand Image dan Perceived Value secara simultan berpengaruh secara signifikan terhadap Purchase Intention

\section{METODE PENELITIAN}

Populasi dalam penelitian ini adalah responden yang merupakan Konsumen Situs Online Tokopedia. Dengan sampel penelitian adalah 200 responden. Metode pengambilan sampel yang digunakan nonprobability sampling dengan purposive sampling. Berdasarkan data yang terkumpul, mayoritas karakteristik dari responden pada penelitian ini adalah wanita $(66 \%)$, berusia 20-30 tahun (56\%) yang berpenghasilan rata-rata diatas Rp. 3.000 .000 (79\%). 
Dalam penelitian ini, variabel social media, electronic word of mouth, brand image, dan perceived value merupakan variabel independent, sedangkan purchase intention adalah variabel dependent. Untuk mengukur variabel ini, menggunakan Skala Likert 5 poin dengan 1 menunjukkan "sangat tidak setuju" dan 5 menunjukkan "sangat setuju". Metode analisis data yang digunakan dalam penelitian ini adalah analisis regresi linier berganda. Sedangkan, untuk uji asumsi seperti uji normalitas, uji multikolinearitas dan uji heteroskedastisitas telah dilakukan sebelumnya dan hasilnya menunjukkan semua uji asumsi sudah terpenuhi. Pengujian dalam penelitian ini menggunakan program SPSS 25.0. Taraf signifikansi yang digunakan dalam penelitian ini adalah 0,05 .

Tabel dibawah ini menunjukkan pengukuran masing-masing variabel dan sumbernya:

\section{Tabel 1}

Variabel dan Pengukuran

\begin{tabular}{|l|c|c|}
\hline \multicolumn{1}{|c|}{ Variabel } & $\begin{array}{c}\text { Jumlah } \\
\text { Item }\end{array}$ & Sumber \\
\hline Variabel Independen & & \\
\hline 1. Social Media & 8 & Prasad et al. (2017); Prasad et al. (2019); Heuer (2010) \\
\hline 2. Electronic Word of Mouth & 7 & Prasad et al. (2017); Prasad et al. (2019); Goyette et al. (2010) \\
\hline 3. Brand Image & 8 & Lien et al. (2015); Kotler dan Keller (2012) \\
\hline 4. Perceived Value & 10 & Yuan et al. (2020); Sweeney dan Soutar (2001) \\
\hline Variabel Dependen & & Semuel dan Setiawan (2018); Yuan et al. (2020) \\
\hline 1. Purchase Intention & 7 & \multicolumn{2}{|c|}{ Puran } \\
\hline
\end{tabular}

ANALISA DAN PEMBAHASAN

Tabel 2

Hasil Pengujian Hipotesis

\begin{tabular}{|c|l|c|c|c|}
\hline & Hipotesis & $\begin{array}{c}\text { Std. } \\
\text { Coefisien }\end{array}$ & Sig. & Kesimpulan \\
\hline H1 & $\begin{array}{l}\text { Terdapat pengaruh positif social media terhadap purchase } \\
\text { intention }\end{array}$ & 0,086 & 0.034 & Tidak Ditolak \\
\hline H2 & $\begin{array}{l}\text { Terdapat pengaruh positif electronic word of mouth terhadap } \\
\text { purchase intention }\end{array}$ & 0,190 & 0.000 & Tidak Ditolak \\
\hline H3 & $\begin{array}{l}\text { Terdapat pengaruh positif brand image terhadap purchase } \\
\text { intention }\end{array}$ & 0,159 & 0.021 & Tidak Ditolak \\
\hline H4 & $\begin{array}{l}\text { Terdapat pengaruh positif perceived value terhadap purchase } \\
\text { intention }\end{array}$ & 0,548 & 0.000 & Tidak Ditolak \\
\hline
\end{tabular}

Berdasarkan hasil pengujian hipotesis, maka dapat disimpulkan bahwa social media, electronic word of mouth, brand image, dan perceived value berpengaruh positif terhadap purchase intention. Ini berarti konsumen memiliki minat pembelian yang cukup tinggi terhadap produk atau merek yang ditawarkan di situs online Tokopedia, karena adanya social media, electronic word of mouth, brand image dan perceived value yang baik. Hipotesis $\mathrm{H} 1 \mathrm{dan} \mathrm{H} 2$ ini sesuai dengan penelitian Prasad et al. (2017) mengemukakan bahwa social media, electronic word of mouth memiliki hubungan positif terhadap purchase intention. Ketika konsumen akan membeli sesuatu, konsumen akan lebih memilih untuk membeli produk atau merek yang sudah dia ketahui sebelumnya melalui sosial media dan konsumen mengevaluasi kembali melalui aplikasi dengan membaca review-review positif tentang produk yang akan dibeli. Selanjutnya hipotesis H3 sesuai dengan Lien et al. (2015) menemukan brand image mempunyai hubungan positif terhadap purchase intention. Brand image yang lebih baik akan menampilkan kualitas produk yang lebih baik di mata konsumen. Brand image yang baik akan memudahkan pembeli dalam melakukan pembelian karena tidak semua calon konsumen mempunyai informasi atas kualitas dan waktu untuk membandingkan produk satu dengan lainnya sehingga yang akan dijadikan acuan adalah merek yang memiliki citra yang baik. Kemudian untuk hipotesis H4 juga sudah sesuai dengan Yuan et al. (2020) bahwa perceived value berpengaruh positif terhadap purchase intention. Konsumen merasakan nilai positif dari produk sehingga bersedia untuk membelinya. Semakin besar manfaat produk yang dirasakan 
oleh konsumen, semakin tinggi nilai persepsi yang konsumen atributkan pada produk tersebut, sehingga akan meningkatkan minat beli konsumen.

Dengan demikian maka seluruh hipotesis penelitian ini terbukti dengan adanya data secara empiris. Purchase intention dapat diprediksi oleh social media, electronic word of mouth, brand image, dan perceived value. Dengan demikian, maka dapat dilihat bahwa purchase intention dalam hal ini dapat dipengaruhi oleh adanya interaksi melalui social media, konsumen memperoleh informasi produk atau merek, dengan brand image yang baik, perceived value yang dirasakan oleh konsumen terhadap produk dari situs online Tokopedia.

\section{KESIMPULAN DAN SARAN Kesimpulan}

Berdasarkan hasil penelitian dan pembahasan yang telah dilakukan, bahwa seluruh faktor dalam penelitian ini, yaitu social media, electronic word of mouth, brand image, dan perceived value memiliki pengaruh terhadap purchase intention. Dalam meningkatkan minat pembelian konsumen, tidak cukup hanya mengandalkan kekuatan daripada brand dan inovasi, tetapi perusahaan perlu memperhatikan faktor lain. Social media, electronic word of mouth, brand image, dan perceived value juga menjadi sangat penting karena berpengaruh terhadap berjalannya suatu bisnis. Melalui social media informasi mengenai suatu produk dapat tersebar dengan cepat. Penyebaran informasi oleh konsumen melalui internet dan sosial media dikenal dengan istilah $e W O M$. Sebelum membeli suatu produk, konsumen akan melakukan pencarian mengenai suatu produk dan melihat ulasan mengenai produk tersebut. Demikian dengan brand image, perusahaan yang membangun image yang baik akan membuat minat beli konsumen meningkat, produk dengan brand yang terkenal, adanya asumsi bahwa brand terkenal lebih dapat diandalkan, selalu tersedia dan mudah dicari, dan memiliki kualitas yang tidak diragukan. Begitu juga dengan perceived value, perceived value yang lebih tinggi membuat minat beli yang lebih tinggi semakin banyak value yang dirasakan, konsumen akan melakukan pembelian lagi.

\section{Saran}

Peneliti menyarankan agar perusahaan harus tetap memperhatikan faktor atau variabelvariabel social media, electronic word of mouth, brand image, dan perceived value dalam menjalankan kegiatan operasional perusahaan. Hal ini dikarenakan, hasil temuan dalam penelitian bahwa keempat faktor tersebut mempunyai pengaruh positif dan signifikan dalam menciptakan minat pembelian konsumen.

\section{IMPLIKASI MANAJERIAL}

Berkaitan dengan hasil penelitian ini, maka dapat disampaikan beberapa implikasi manajerial yang bisa diterapkan oleh perusahaan khususnya Situs Online Tokopedia. Peneliti menyarankan pentingnya melakukan strategi brand marketing. Brand image yang diberikan oleh situs online Tokopedia sudah baik dan tertanam kuat di benak konsumen. Bahkan ini menjadi faktor penting bagi situs online Tokopedia untuk mempengaruhi setiap konsumennya dalam melakukan pembelian ulang. Peneliti menyarankan bahwa sebaiknya brand Tokopedia semakin diperluas tidak hanya dalam blog atau brand yang tertera pada toko online-nya dan berpatokan pada penjual yang mendaftarkan diri di Tokopedia, tetapi juga bisa bekerjasama untuk memasukkan produk dari toko-toko offline dan memasang brand dari Tokopedia di tokotoko tersebut. Selain itu, Tokopedia juga dapat melakukan roadshow kampus atau open stand di beberapa tempat sekaligus melakukan sarana promosi supaya semakin banyak orang yang aware dan ingin melakukan pembelian di Tokopedia.

\section{DAFTAR PUSTAKA}

Goyette, I., Ricard, L., Bergeron, J., \& Marticotte, F. (2010). E-WOM scale: Word-of-mouth measurement scale for e-services context. Canadian Journal of Administrative Sciences, 
27(1), 5-23. https://doi.org/10.1002/cjas.129

Kotler, P., \& Keller, K. L. (2012). Marketing management (14th ed.). Pearson Education, Inc. Kotler, P., \& Keller, K. L. (2016). Marketing management (15th ed.). Pearson Education, Inc. Lenarto, S., Putra, A. Y. Y. W. T., \& Rahmawati, V. (2018). Pengaruh brand image dan price image terhadap purchase intention dengan store image sebagai variabel intervening pada IBOX Store di World Trade Center (WTC) di Surabaya. Jurnal Ilmiah Mahasiswa Manajemen, 6(2), 99-111.

http://journal.wima.ac.id/index.php/JUMMA/article/view/1768

Lien, C. H., Wen, M. J., Huang, L. C., \& Wu, K. L. (2015). Online hotel booking: The effects of brand image, price, trust and value on purchase intentions. Asia Pacific Management Review, 20(4), 210-218. https://doi.org/10.1016/j.apmrv.2015.03.005

Lim, W. M., Yong, J. L. S., \& Suryadi, K. (2014). Consumers' perceived value and willingness to purchase organic food. Journal of Global Marketing, 27(5), 298-307. https://doi.org/10.1080/08911762.2014.931501

Litvin, S. W., Goldsmith, R. E., \& Pan, B. (2008). Electronic word-of-mouth in hospitality and tourism management. Tourism Management, 29(3), 458-468. https://doi.org/10.1016/j.tourman.2007.05.011

Moslehpour, M., Dadvari, A., Nugroho, W., \& Do, B. R. (2021). The dynamic stimulus of social media marketing on purchase intention of Indonesian airline products and services. Asia Pacific Journal of Marketing and Logistics, 33(2), 561-583. https://doi.org/10.1108/APJML-07-2019-0442

Mursid, F. (2020). Kominfo: Pengguna internet di Indonesia capai 175,5 juta. Republika.Co.Id. https://republika.co.id/berita/qhgibx335/kominfo-pengguna-internetdi-indonesia-capai-1755-juta-jiw

Prasad, S., Garg, A., \& Prasad, S. (2019). Purchase decision of generation Y in an online environment. Marketing Intelligence and Planning, 37(4), 372-385. https://doi.org/10.1108/MIP-02-2018-0070

Prasad, S., Gupta, I. C., \& Totala, N. K. (2017). Social media usage, electronic word of mouth and purchase-decision involvement. Asia-Pacific Journal of Business Administration, 9(2), 134-145. https://doi.org/10.1108/APJBA-06-2016-0063

Priansa, D. J. (2016). Pengaruh E-WOM dan persepsi nilai terhadap keputusan konsumen untuk berbelanja online di Lazada. Ecodemica, 4(1), 117-124. https://doi.org/10.31294/JECO.V4I1.353

Resmawa, I. N. (2017). Pengaruh brand image dan product knowledge terhadap purchase intention dengan green price sebagai moderating variabel pada produk The Body Shop di Surabaya. Jurnal Aplikasi Manajemen, Ekonomi Dan Bisnis, 1(2), 1-11. https://jameb.stimlasharanjaya.ac.id/JAMEB/article/view/20

Semuel, H., \& Setiawan, K. Y. (2018). Promosi melalui sosial media, brand awareness, purchase intention pada produk sepatu olahraga. Jurnal Manajemen Pemasaran, 12(1), 47-52. https://doi.org/10.9744/pemasaran.12.1.47-52

Wang, Y.-H., \& Tsai, C.-F. (2014). The relationship between brand image and purchase intention: Evidence from award winning mutual funds. The Relationship between Brand Image and Purchase Intention: Evidence from Award Winning Mutual Funds, 8(2), 2740. http://www.theibfr2.com/RePEc/ibf/ijbfre/ijbfr-v8n2-2014/IJBFR-V8N2-2014-3.pdf

Yuan, C., Wang, S., \& Yu, X. (2020). The impact of food traceability system on consumer perceived value and purchase intention in China. Industrial Management and Data Systems, 120(4), 810-824. https://doi.org/10.1108/IMDS-09-2019-0469

Zeithaml, V. A. (1988). Consumer perceptions of price, quality, and value: A means-end model and synthesis of evidence. Journal of Marketing, 52(3), 2. https://doi.org/10.2307/1251446 